\title{
Hepatitis B surface antigenemia (HBsAg) among pregnant women in southern Nigeria
}

\author{
$*$ Utoo B'T \\ Department of Obstetrics \& Gynaecology, College of Health Sciences, Benue State University, Makurdi, \\ GPO Box 239 Makurdi, Nigeria
}

\begin{abstract}
Background: Hepatitis B virus (HBV) infection is one of the most common public health problems worldwide. Over one million people die annually of HBV- related chronic liver disease. Maternal to fetal transmission from chronic carriers exceeds $90 \%$ and accounts for up to $40 \%$ of the world's chronic carriers in endemic areas.

Methods: This was a descriptive study which involved Serial recruitment of 836 women attending the antenatal clinic at a health facility in Cross-River State, Nigeria from $1^{\text {st }}$ January to $30^{\text {th }}$ June 2010. HBsAg screening was done using an ELISA test.

Results: Fifty five (6.6\%) of the 836 women screened tested positive for HBsAg. The mean age and parity of sero-positive subjects was $26.9 \pm 5.0$ (range 18-38 years) and $2.2 \pm 1.2$ ( 0 to 5 ) respectively. The prevalence was more in women who were farmers $(29.1 \%)$ and those with either none or low level of formal education $(67.2 \%)$.

Conclusion: Sero-prevalence of $6.6 \%$ among pregnant women is reported. Women education, economic empowerment and public enlightenment programmes focused on modification of risky social lifestyle is recommended. Efforts to promote routine screening of pregnant women, immunization and vaccination of infants should be sustained.

Keywords: Sero-prevalence, Hepatitis B virus, routine screening, immunization.
\end{abstract}

African Health Sciences 2013; 13(4): 1139 - 1143 http://dx.doi.org/10.4314/ahs.v13i4.39

\section{Introduction}

Hepatitis B virus (HBV) infection is one of the most common public health problems worldwide. It has been estimated that 350 million people world-wide are chronic carriers of hepatitis B virus ${ }^{1}$. These chronically infected persons are at a high risk of death from liver cirrhosis and hepatocellular carcinoma ${ }^{2,3}$. Over one million people die annually of HBV-related chronic liver disease ${ }^{4}$.

In Europe and America, chronic carriers of HBV are found in less than $2 \%$ of the population. The sero-prevalence rates of $0.44 \%, 1.4 \%, 10 \%$ were reported in Netherland, Germany and Hong Kong respectively. Studies done in different regions of Turkey showed that the prevalence rates range from $2 \%$ to $14.3 \%{ }^{2}$. In Africa, it is believed that more

\author{
*Corresponding author: \\ Dr. Utoo Bernard T \\ Department of Obstetrics \& Gynaecology \\ College of Health Sciences \\ Benue State University, Makurdi \\ GPO Box 239 Makurdi \\ Benue State, Makurdi Benue 970001 \\ Nigeria \\ Tel: +234(0)8033725168 \\ Email: bernardutoo@yahoo.com
}

than half of the population becomes infected during their reproductive lifetime and about $8 \%$ of inhabitants become chronic carriers ${ }^{2}$.

Hepatitis B virus is transmitted primarily through parenteral and sexual exposure to HBsAg positive blood or other body fluid ${ }^{5}$. This double stranded DNA virus belonging to hepadnaviridae family is of clinical significance to the Obstetrician. This is due to the fact that viral hepatitis during pregnancy is not only associated with the high risk of maternal complications but also a high rate of vertical transmission causing fetal and neonatal hepatitis ${ }^{4}$.

Perinatal transmission of HBV occurs if the mother has had acute HBV infection during late pregnancy, or if she is a chronic carrier. Neonatal contamination does occur during labour and delivery ${ }^{6}$.Vertical transmission from chronic carriers exceeds $90 \%$ and accounts for up to $40 \%$ of the world carriers in endemic areas ${ }^{6,7,8,9}$.

If contaminated, the neonate becomes a chronic carrier himself in $80 \%$ to $90 \%$ of cases and is prone to cirrhosis and hepatocellular carcinoma in adult life ${ }^{6}$. When the mother is positive for viral DNA in her serum, transmission rate is estimated at $90 \%{ }^{7}$. If the mother is negative for viral DNA in the serum, transmission rate is about $10 \%$ to $30 \%{ }^{7}$. 
Similarly, a positive test for $\mathrm{Hb}$ e Ag viral protein which is a marker for patients at high risk for transmission of the disease indicates the individual has a high level of the virus ${ }^{8,9}$. However, the absence of e-antigen does not necessarily exclude active viral replication because; some patients have mutant viruses that do not give rise to e-antigen. The disappearance of $\mathrm{Hbe} \mathrm{Ag}$ and rise in anti-Hbe antibodies is associated with a decline in vireamia ${ }^{8,10}$.

A study done in Canada showed that hepatitis in pregnancy is not associated with increase abortion rate, still birth or congenital malformation ${ }^{6}$. However, prematurity is likely to increase if hepatitis is acquired in the last trimester ${ }^{6}$. Some studies have also demonstrated that infants born to mothers with acute infection during pregnancy have low birth weights ${ }^{2}$.

Hepatitis $B$ virus infection in pregnancy could be detected through the 3-part hepatitis B blood panel. These includes hepatitis B surface Antigen ( $\mathrm{HBsAg}$ ), hepatitis B surface Antibody (HBsAb or anti-Hbs) and hepatitis B core Antibody $\left(\mathrm{HbcAb}\right.$ or anti-HBc) ${ }^{12}$. The prevention of HBV infection among pregnant women should be a major concern of every reproductive health expert. Notable agencies such as the United States Preventive Services Task Force (USPSTF), Centres for Disease Control (CDC) and Advisory Committee on Immunization Practices (ACIP) have all strongly recommended universal $\mathrm{HBsAg}$ screening of pregnant women to prevent perinatal HBV transmission and Mother-to-child infection of HBV 13.

Despite these strong recommendations based on good evidence in maternal-fetal medical practice, several heath care centers in developing nations of the world, including Nigeria, are yet to make HBV screening in pregnancy a routine practice. Routine screening in pregnancy for some of these infectious pathogens have been restricted to blood donors. This has negatively affected the prevention, diagnosis and early treatment of the infection in pregnancy.

It is true that in resource -constrained countries like Nigeria, adopting and implementing a new preventive measure requires not only the proof of the existence of the infection but also its magnitude and the trend of the problem in the community ${ }^{11}$. This also includes the implication of not adopting timely intervention measures ${ }^{11}$. Although, some studies on sero-prevalence of HBV infection in pregnancy have been done in Nigeria, few have taken place in secondary health care centers in the Southern region of the country.

There is need therefore to assess the current prevalence and the trend in the spread of the infection. This study was thus designed to assess the sero-prevalence of HBsAg in pregnancy in a secondary health care facility in South-South, Nigeria.

\section{Methods}

\section{Study setting and design}

The study was carried out at the Sacred Heart Hospital (SHH) Obudu, Cross-River State, Nigeria. Obudu is an urban community whose inhabitants are civil servants, students, traders and farmers. The $\mathrm{SHH}$ is the largest in the area and offers clinical services ranging from primary to secondary care. The center also provides service to patients from neighboring Local Government Areas (LGAs) to Obudu LGA in Cross-River State. This was a descriptive study carried out from $1^{\text {st }}$ January to $30^{\text {th }}$ June 2010.

\section{Subjects}

A total of 836 subjects who attended the antenatal booking clinic and consented were recruited serially into the study by the researcher. They were offered pre and posttest counseling by trained antenatal nurses.

\section{Ethical approval}

The hospital gave ethical clearance and approval for the study to be conducted.

\section{Procedure}

During the initial antenatal investigation, five milliliters of blood was taken from each subject for HBsAg test by laboratory scientist. The blood samples were code-labelled to ensure confidentiality. After centrifugation, the samples were analyzed at the hospital laboratory for HBsAg. The test was performed using a rapid Enzyme Linked immunosorbent Assay (ELISA) with test kit by Biotec Lab Ltd, Ipswich, Suffolk, IP5 3TP UK; in accordance with the manufacturer's instructions. All reactive samples were further tested with HBV ELISA kit from DIA-PRO Diagnostic Bioprobes Srl via columella, Italy. Those who remained reactive were considered positive for HBV. All subjects, irrespective of their sero-status were offered post test counselling. 
Data analysis

Data collected included the serological status of subjects studied and their socio-demographic characteristics. This was done through the use of a proforma. The variables of sero-positive subjects were analyzed using EPI Info Statistical software Version 3.2.2.

\section{Results}

Eight hundred and thirty six (836) subjects were screened for HBsAg, out of which 55(6.6\%) tested positive (table 1).

The mean age and parity of sero-positive subjects were $26.9 \pm 5.0$ years (range 18-38 years) and $2.2 \pm 1.2(0$ to 5$)$ respectively. The age group mostly affected was 24 to 28 year old. Thirty two point seven percent (32.7\%) had secondary level of education, $12.7 \%$ primary, $30.9 \%$ tertiary and $23.7 \%$ did not have any formal education. Farmers constituted 29.1\%, civil servants $23.6 \%$, traders $20.0 \%$, students $14.5 \%$, teachers $5.5 \%$ and others $7.3 \%$ (table 2).

Table 1: HBsAg serology of subjects studied

$\begin{array}{lll}\text { Serology } & \text { Number } & \text { Percentage } \\ \text { Positive } & 55 & 6.6 \\ \text { Negative } & 781 & 93.4 \\ \text { Total } & \mathbf{8 3 6} & \mathbf{1 0 0 . 0}\end{array}$

Table 2: Socio-demographic features of HBsAg positive subjects

$\begin{array}{lll}\text { Age group } & \text { Frequency } & \text { Percentage } \\ \text { d"18 } & 1 & 1.8 \\ \text { 19-23 } & 14 & 25.5 \\ 24-28 & 23 & 41.8 \\ 29-33 & 10 & 18.2 \\ 34-38 & 7 & 12.7 \\ \text { Occupation } & & \\ \text { Farming } & 16 & 29.1 \\ \text { Civil Servants } & 13 & 23.6 \\ \text { Schooling } & 8 & 14.5 \\ \text { Trading } & 11 & 20.0 \\ \text { Others } & 4 & 7.3 \\ \text { Teaching } & 3 & 5.5 \\ \text { Education } & & \\ \text { None } & 13 & 23.6 \\ \text { Primary } & 7 & 12.7 \\ \text { Secondary } & 18 & 32.7 \\ \text { Post-Secondary } & 17 & 30.9 \\ \text { Parity } & & \\ \text { 0 } & 5 & 9.1 \\ \text { 1-2 } & 27 & 49.1 \\ \text { 3-4 } & 22 & 40.0\end{array}$

African Health Sciences Vol 13 Issue 4 December 2013
Figure 1 Shows the prevalence of HBsAg among pregnant women in some parts of south -south zone in Nigeria, namely Benin-city (2.2\%), Port-Harcourt (4.3\%) and Obudu $(6.6 \%)$. Figure 2 demonstrates regional variations among the three zones out of the six in the country. The southeast represented by Enugu reported 4.3\%, south-west represented by Lagos reported $6.08 \%$ and south-south represented by Obudu reported 6.6\%. This showed a relatively higher prevalence in south-south zone in Nigeria.

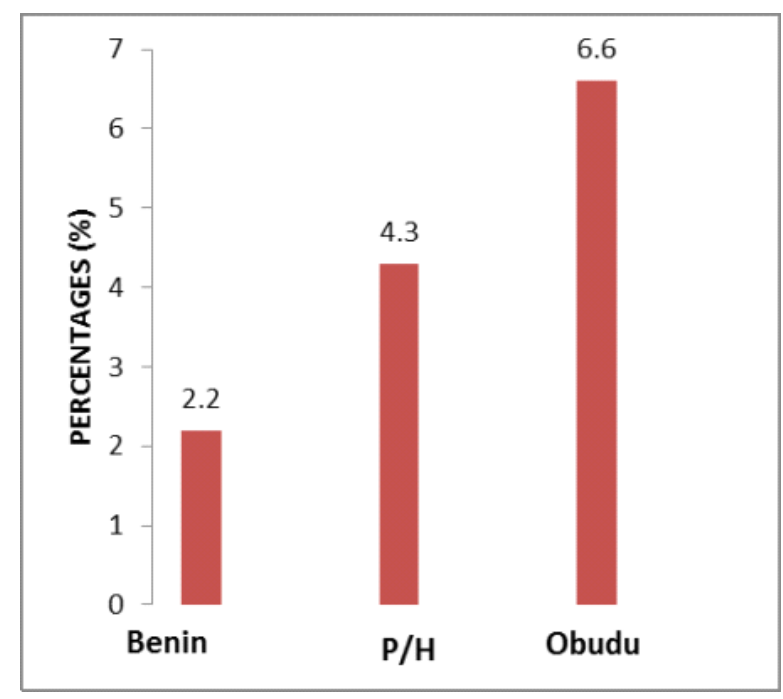

Figure 1: Sero-prevalence of $\mathrm{HBV}$ in some urban centers in South-South Nigeria

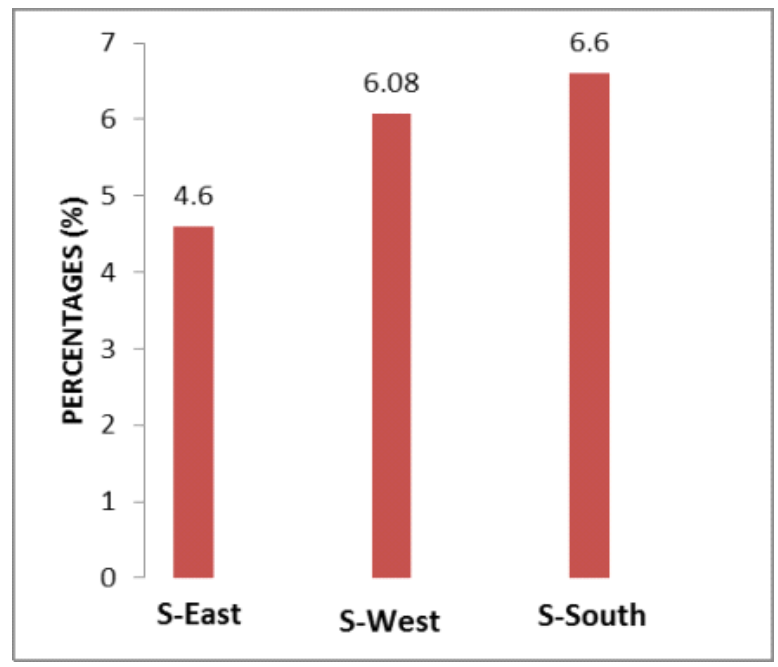

Key: S-East (Enugu), S-West (Lagos) and S-South (Obudu).

Figure 2: Comparison of sero-prevalence of $\mathrm{HBV}$ among three centers in the various zones in Southern part of Nigeria 


\section{Discussion}

The sero-prevalence rate of HBV Infection in pregnancy in the study was $6.6 \%$. This is higher than the prevalence of $2.2 \%$ reported in Benin City ${ }^{11}$, $4.6 \%$ in Enugu $^{14}$ and $4.3 \%$ in Port-Harcourt ${ }^{15}$. The prevalence, though higher, is comparable with the $6.08 \%$ reported in Lagos ${ }^{16}$, Nigeria.

On the international scene, studies have reported various prevalence rates among pregnant women. In Brazil, a prevalence of 1.64\%, France $0.29 \%$, Italy $1.1 \%$, Saudi Arabia $2.44 \%$, Pakistan $4.6 \%$, India $2.3 \%$, and Turkey $2.1 \%$. In the Persian Gulf, rates of $7.1 \%$ have been reported in Oman and $1.5 \%$ in United Arab Emirate. In Africa, rates of $3 \%$ to $4 \%$ have been reported in Tunisia, $5.6 \%$ in Sudan and an astronomically high rate of $25 \%$ in Zimbabwe 2, 17-20.

Comparing the rate of $6.6 \%$ in this study which was carried out at Obudu, with the $2.2 \%$ in Benin (reportedly carried out eight years ago) and $4.3 \%$ in Port-Harcourt (reportedly carried out five years ago) there is obviously a rising trend of $\mathrm{HBV}$ infection among pregnant women in the south-south zone of Nigeria. The recent prevalence in the South -South zone which is reported in this study is also higher than that of the South- East (represented by Enugu) and South- West (represented by Lagos) zones of the country. This is an indication that there is an urgent need to implement intervention measures by stake holders in the health sector to halt and reverse the unfortunate trend of events.

Another important concern demonstrated in the study is the infection of teenage primigravid women. The acquisition of HBV infection among this group of women may most likely be through heterosexual contacts, given that the age at coitarche has reduced over the years. Rabiu et al. in a study of risk factors for hepatitis B virus infection among pregnant women in Lagos, Nigeria, reported that early age at sexual debut below 19 years was a significant contributor ${ }^{16}$. Furthermore, more babies at risk of acquiring the infection are likely to be born through these young women who are just beginning their reproductive career. The finding that infection was more among women who either had none or low level of formal education and were mostly involved in agricultural / commercial activities could suggest risky social behavioral practices as a possible means of contacting the infection.

Several studies have shown that screening of pregnant women for HBV infection on the basis of the presence of risk factors may not be effective
${ }^{14}$. Hence routine screening is advocated based on the recommendation of $\mathrm{WHO}$ and $\mathrm{CDC}^{12-15}$. Immunization has been found to be the most effective way of controlling $\mathrm{HBV}^{21}$. The vaccine has an outstanding record of safety and efficacy, and it is $95 \%$ effective in preventing development of the chronic carrier state ${ }^{21}$. It is advisable that infants born to $\mathrm{HBs} A g$-positive mothers should receive hepatitis $B$ vaccine and $0.5 \mathrm{ml} \mathrm{HBIG}$ within 12 hours of birth. The infected mothers were advised to strictly comply with this recommendation inoder to reduce the risk of their babies being infected after birth.

Pregnancy has not been shown to be a contraindication for vaccination for $\mathrm{HBV}^{2}$. No apparent risk for adverse effects to the developing fetus has been demonstrated when $\mathrm{HBV}$ vaccine was administered to pregnant women even in early pregnancy ${ }^{2}$. Therefore, those pregnant women who are identified to be at risk for HBV infection during pregnancy should be vaccinated ${ }^{2}$. With studies showing that lamivudine therapy for HBV in pregnancy can effectively reduce the risk of intrauterine infection, its use in resource rich -settings may also be helpful in preventing maternal-infant HBV transmission ${ }^{22-26}$. Studies had not shown that vaccination of women who are already infected could be helpful in preventing vertical transmission. Thus, the women who tested positive to HbsAg were not vaccinated; they were however sent to liver specialist for expert medical care.

\section{Conclusion}

With the rising trend in HBV infection among pregnant women in the south-south region of the country, health education of the public that is aimed at the modification of risky social lifestyle, routine screening of pregnant women, and immunization of those at risk and mass vaccination of infants irrespective of maternal HBV status is hereby recommended. In this way, HBV infection, including maternal-fetal transmission may be reduced remarkably.

\section{Acknowledgement}

Prof. Isaac Lar and Prof. EO Nwokedi proof read the initial manuscript. The nurses in the antenatal unit and laboratory scientists of the hospital were very helpful. Thanks to the subjects for their cooperation. 


\section{References}

1. Tosun S Y, Yuceturk M, Benzergil S. The immunization of babies born of HBsAg positive pregnant women. Ege Tip Dergisi 2002; 41(1): 2123.

2. Uyar Y, Cabar C, Balci A. Seroprevalence of hepatitis B virus among pregnant women in Northern Turkey. Hepatitis Monthly 2009; 9(2): 146-149.

3. Arfaoui D, Fkih M, Hafsa AE, Kaabia N, Azzouz M. Hepatitis B and pregnancy. Tunis Med 2010; 88(6): 383-389.

4. Chang MH. Hepatitis B virus infection. Semin Fetal Neonatal Med 2007; 12 (3):160-167.

5. Maddrey WC. Hepatitis B: an important public health issue. J Med Virol 2000; 61(3): 362-366.

6. Levy M, Koren G. Hepatitis B vaccine in pregnancy; maternal and fetal safety. Am J Perinatol 1991; 8(3): 227-232.

7. Ranger-Rogez S, Alain S, Denis F. Hepatitis viruses: mother to child transmission. Pathol Biol (Paris) 2002; 50(9): 568-575.

8. Tong S, Kim KH, Chante C, Wands J, Li J. Hepatitis B virus e Antigen variants. Int J Med Sci 2005; 2(1): 2-7.

9. Olokoba AB, Salawu FK, Danburam A, Olokoba LB, Midala JK, Badung LH et al. Hepatitis B virus infection amongst pregnant women in northEastern Nigeria-A call for action. Nig J Clin Pract 2011; 14(1): 9-13.

10. Yang HI, Lu SN, You SL, Sun CA, Wang LY,Hsiao $\mathrm{C} \mathrm{K}$ et al. Hepatitis B e Antigen and the risk for hepatocellular carcinoma. N Engl J Med 2002; 347(3): 168-174.

11. Onakewhor JUE, Okonofua FE. The prevalence of dual human immunodeficiency virus/Hepatitis $\mathrm{C}$ virus (HIV/HCV) infection in asymptomatic pregnant women in Benin City, Nigeria. Afr J Reprod bealth 2009; 13(2): 97-108.

12. Hepatitis B Foundation. Hepatitis B guidelines for pregnant women. Available at: info@www.hepb.org. November 2010.

13. Campbell KP, Lindley MC, Lentine D, Bhatt A. Hepatitis B virus evidence- statement; screening, immunization and treatment. In: Campbell KP, Lanza A, Dixon R, Chattopadhyay S, Molinari N, Finch RA, eds. A purchaser's guide to clinical preventive services: moving science into coverage. Washington DC. National Business Group on Health, 2006.

14. Obi SN, Onah HE, Ezugwu FO. Risk factors for hepatitis B infection during pregnancy in a Nigerian Obstetric population. J Obstet Gynaecol 2006; 26(8): 770-772.

African Health Sciences Vol 13 Issue 4 December 2013
15. Akani CI, Ojule AC, Opurum HC, Ejilemele AA. Seroprevalence of hepatitis B surface antigen (HBsAg) in pregnant women in Port Harcourt, Nigeria. Niger Postgrad Med J 2005; 12(4): 266270.

16. Rabiu KA, Akinola OI, Adewunmi AA, Omololu OM, Ojo TO. Risk factors for hepatitis B virus infection among pregnant women in Lagos, Nigeria. Acta Obstet Gynecol Scand 2010; 89(9): 1024-1028.

17. Biswas SC, Gupta I, Ganguly NK, Chawla Y, Dilawari JB. Prevalence of hepatitis B surface antigen in pregnant mothers and its perinatal transmission: Trans R Soc Trop Med Hyg 1989; 83(5): 698-700.

18. Khalil MK, Al-Mazrou YY, Al-Jeffri M, AlGhamdi YS, Mishkhas A, Bakhish M, et al. Sero survey of hepatitis B surface antigen in pregnant Saudi women .East Mediterr Health J 2005; 11(4): 640-647.

19. Madzime S, Adem M, Mohomed K, Woelk GB, Mudzamiri S, Williams MA. Hepatitis B virus infection among pregnant women delivering at Maternity Hospital Harare Zimbabwe, 1996-1997. Cent Afr J Med 1999; 45(8): 195-198.

20. Sami S, Korejo R, Bhutta SZ. Prevalence of hepatitis B and C: a Jinnah postgraduate Medical Center experience. J Obstet Gynaecol Res 2009; 35(3): 533-538.

21. Emechebe GO, Emordi IJ, Ikefuna AN, Ilechukwu GC, Igwe WC, Ejiofor OS et al. Hepatitis B virus Infection in Nigeria-a Review. Niger Med J 2009; 50(1): 18-22.

22. Li XM, Yang YB, Hou HY, Shi ZJ, Shen HM, Teng BQ, et al. Interruption of HBV intrauterine transmission: A clinical study. World J Gastroenterol 2003; 9(7): 1501-1503.

23. Xu WM, Cui YT, Wang L, Yang H, Lian ZQ, Li $\mathrm{XM}$, et al. Lamivudine in late pregnancy to prevent perinatal transmission of hepatitis $B$ virus infection: a multicenter randomized double blind placebo-controlled study. J Viral Hepatol 2009; 10(2): 94-103.

24. Su GG, Pan KH, Zhao NF, Fang SH, Yang DH, Zhou Y. Efficacy and safety of lamivudine treatment for chronic hepatitis B in pregnancy. World J Gastroenterol 2004: 10(6): 910-912.

25. Hiratsuka M, Minakami H, Koshizuka S, Sato I. Administration of interferon-alpha during pregnancy: effects on fetus. J Perinat Med 2000; 28(5): 372-376.

26. Bukbuk DN, Bassi AP, and Mangoro ZM. Seroprevalence of hepatitis B surface antigen among primary school pupils in rural Hawal valley, Borno State, Nigeria. Journal of Community Medicine and Primary Health care 2005; 17(1): 20-23. 